\title{
EFFECT OF DETARY PROTEIN AND LYSINE LEVELS ON GROWTH PERFORMANCE AND IMMUNE RESPONSE IN BROILER CHICKS
}

\author{
A. M., Orma; T. I., Mohamed Bama, M. Gonda \\ Dept. of Nutrkfon \& Nitnutunal Deflclency Dlseases, Faculty or Vet. Med. Mansoura Unwersity
}

\begin{abstract}
The present work was carrled out to study the effect of decreasing the dletary pro tein content by 10\% (LCP-diet) with supplementation of lysine 10.0 .2 , and $0.4 \%$ ) over the recommended level in braller diets on growth perfornance, carcass traits, blood metatwoltes, imnune responise. One day old Cobb chicks (120) were used. The chicks were distributed rardomly into 4 groups and fed $23 \%$ or $20.7 \% \mathrm{CP}$ for the starter diets, 20 or $18.2 \%$ CP for the grower and 18 or $16.2 \% \mathrm{CP}$ for the finlsher dlets with different dietary lysine level (1.1, 1.29 or 1.45\%) for stanter diets, 1, 1.22 or 1.49 for the groner diet and 0.85 .1 .05 or $1.25 \%$ for the finisher dlets, respectuely and $3200 \mathrm{Kcal} M E / \mathrm{Kg}$. The chicks were vaccinated against Auian influenza. Newcastle and Gumboro diseases at proper trme. The growth perfornance indlces (body wetght, feed intake and feed conversion ratho) were measiued. Bload samptes were collected from the broliers at 14,21 and 28 days of age without anticoaguluni for separation of sera to detect titer of antrbodtes against Newcastte disease uaccine using haemagglutination inhlbition test (HI) as indicatue of birds immune response in the duferent experimental groups and also at 42 days of age. blood samples collected for delernination of senum metabolltes. At the end of the experiment. 5 chicks from each group uere slaughtered to obtain some of the carcass traits.
\end{abstract}

The results revealed that body weight and feed converston rath of the broller fed $10 \%$ LCP.diet supplemented with $0.4 \%$ lysine aboue that recommended for the broilers signiflcandy improved on comparison to those fed the LCP diets supplemented with 0 , $0.2 \%$ Iysthe. Feeding the broller chicks the LCP diet decreased the body webht gatn and uncreased the feed conversion ratio. The abdominal fat in the cancass of the broiler chicks fed LCP-dtet supplemented with $0.4 \%$ lystre were lower than those fed on the diets supplemented with $0,0.2 \%$ lysine. Feeding LCP.diet supplemiented with $0.4 \%$ lystne increased serum total proteln, alburnin, and globulln and decreased serm tatul lypids, cholesterol, iriglycerides, low densty liproprotein and high density lipoproteir.

It can be concluded that feeding the broiler chicks on LCP.dlet supptemented with $0.4 \%$ lysine diet resulted in better growih perfornance, lower total lipuds. cholesterol, 
Inglycerides, bw density lipoprotein and high denslty lipoprotein and higher total proteln. albumin, globulin on comparing to those fed 0 or $0.2 \%$ lystre supplemented diet. Supplementing the low protein diet with 0.496 lystne improved the HI titer in the broilers vaccinated against NDV at 14.21 and 28 days of age.

\section{INTRODUCTION}

Malnutrition has been Identfled in many countries particularly in the developing countries. Majority of malnourished people live in Asia and Africa (Twe and Onedipe, 2001). thus negatlvely impacting on the phystcal and health condition of its people. Poultry productuon ts one major mean of solving part of this problem (Nworgu et al. 2000). Feeding poultry presents a great challenge to producers and nutritionists in several tropical countries as meetung the mutritional requirements for growing birds constitutes the majorty of cosis assoclated with poultry production (May et al., 1098), and certalnly is becoming an issue of even greater s/gnillcance as the prices of iced Ingredlents contlnue to rise. A large porton of that cast involves in meeting the amulno acld requirements of the blrds (Corzo et al., 2004: Eit et 21., 2005).

The amino acid paltern provided in diets must exactly matches the burds amino acjd requilrements, excesses can be avolded consequently; protein accretion can occur with maximum eflictency, excess detary proteln increased heat production and water consumption whlch increased molsture cuntent of Itter (Alleman and Leclercq, 1997). Lowcring crude protein in the dret could reduce the feed costs and dccreased nitrogen excretyon (Nahm, 2002 and Namroud at al., 2008). and allowed for using of a greater varlety of feed stufts (bidd et al., 2006). whuch can be valuable in Itself as a method to in- crease flextbutty in the choice of locally avallable reed stuffs and potentially decreasing nuctuation in costs. Dletary protedn level therefore, has major eflect on growth performance and overall cost of Intshed product So using of LCP-dlet supplemented with amino acld for broller feedting has been recelvcd greater interests in the recent years in order to reduced feeding costs and environmental pollution (Namrond et al., 2008). The use of synthetic anino acld to meet the amino acid needs of brollers could result in production of cost effective dlets.

In chickens as well as mammals. It has been shown that deflctency or excess of dletary protein (Payae et al. 1090) or amino acIds (Talagbe et at. 1987) altered immune responses. The magnitude of an Immune response and subsequent alterations in nutrent metabollsm is dependent upon a nutri Uonally complete diet (Webel et al., 1098). The eflnclency of dielary protem is primartly dependent upon an aderuacy of lysine and methlonine (most limited amlno acids). So. appropriate supplementation of ration deliclent in these ammo acids markedly improved their protein quallty achhpowanl et al. 1981). With progress in blotechnology, the cost of production of each amino acdd particularly lysine has been slgnificantly redueed. which has been one of the key factors in the expanston of use of amino acids in animal feed. Thereione, the objective of this study is to further evaluate the probabulty of lowering 
the dletary protetn eoncent with lysine supplementation and its effect on growth performance. dressed carcass, serum metabollics and immunocompetence in broller chicks.

\section{MATERIALS AND METHODS}

\section{Birdis, diets and munagement}

A total of 180 one day old Cobb chicks abtained from a cornmercial suppller were randomly distributed into 4 equal triplicate groups (15 ehicks / replicatc) and ratsed in a noor pen bedded with wheat straw to malntaln a good litter. The pen was suppled with leeders. waterers and heaters. The chlcks were tagged using wing number tags. The chicks were fed the respectlve experdmental drets according to the suggested destgn. The diets were formulated to malntaln the requircments of energy $(3200 \mathrm{kcal} \mathrm{ME} / \mathrm{kg}$ ) with decreasing proteln by $10 \%$ than that recommended by MrC (1904) and supplcmentation with bysine by $\{0,0.2 \& 0.4 \%$ of the dlet $\}$ over the recommended. The diets crude protein of the dlets was analyzed according to AOAC [1990]. The composition of the experimental diels is shown In Lahle 1.

The broller chieks werc reared durtng the period from mld of February to first of April. 2009. During the lirst 2 wecks of chicks' age the brooding tempcrature was malntained at $35-32^{\circ} \mathrm{C}$, and then the temperature was gradually lowered till reach to $2^{\circ} \mathrm{C}$ by the beginning of the third wcek of age: The pen was naturally ventllated and clectric light was conthruously madntalned 124 hours/day). The diets and water were avallable ad libitum throughout the expertmental period (6 wceks). The chicks were vaccinated against avian Imflumas by subeutaneous injection and
Newcastle disease at $8^{\text {th }}$ day of age by HitchnerBl and at $18^{\text {th }}, 28^{\text {th }}$ days of age by lasola vacolnc In drinklng waler and against Gurn borc at $10^{\text {th }}$ and $20^{\text {th }}$ days of age in drinking water.

\section{lndices of broller performance, dreased carcass and abdominal fat}

The ehlcks were welghed at one day old to obtain the average Inltal body weight then weyghed every week and the average body weights for the ehicks In each group were wcekly calculated. The average feed intake per chick throughout the experimental pertod (6w) for each group was recorded and leed converslon ratio was calculated. At the end of the expertment, flve blrds from each group were randomly taken and fasted for 12 hours. welghed, staughtered to complete bleeding. drcssed and corsceratcd for determination of the dressed carcass $\%$ and abdominal fat wetght and percent in relation to live budy welght.

\section{Blood sampling, aerum metabolite and Inmune response}

Blood samples werc collected from 5 chitks from each group at 42 days of age via wing vedn puncture. Sera were obtalned by allowing blood samples to coagulate then centrifuged at $3000 \mathrm{rgm}$ for 15 minutes. The separated sera were frozen at $-20^{\circ} \mathrm{C}$ in a dcep frecze un til used for determination of glucose (Trtader and Ann, 1809), total Ilpld (Zollner and Edrech, 1962). Criglycerides (Fansutl and Frecipe, 1292]. eholesterol (Allaln et al. 1974), high density Ilpoproteins (Bursteln et al. 1970), low density llpoprotelns (Friede Wald et al., 1972) total protetn (Coamal et al., 1949) and albumin (Doumas at al., 1971) 
using already prepared analyzing chemlcal kits and after the instructions of the producer (GOD-PAP. BIODLAGNOSTIC and STANBIO). Globulln coneentration was calculated as the difference belween cotal proteln and albumin.

Blood samples were collected from 5 chicks of eaeh group at 14,21 and 28 days or age without anticoagulant tor separallon of sera which were used to detect Hter of antibodies against Newcastle dlsease vaccine using haemagglutination Inhibltion test $(\mathrm{HI})$ as indicatlve of bird's Immune response.

\section{Statlatical analysie :}

Data obtatned in the present work were statistically analyzed for analysis of varlance (ANOVA) and least significant difference (LSD) as described by Enedecor and Cochmen (1967).

\section{RESULTS AND DISCUSSION}

Bady weight, body wolvet galn, feed intake, feod converolon ratbo and dreseod carcass :

The data concerned with body welght development (BW], body welght gain (BWG). feed Intake (FI) and reed conversion ratto (FCP] showed that decreasing the dletary proteln level by Jos than that of the NRC (1904) recommendation levels signincantly dccreased $B W, B W G$ and significanty increased the values of FCR of broller chlcks even when lysine 1s supplemented by $0.2 \%$ above that recommended by NRC (1094). However, Incrcasing the level of lysine supplementation to $0.4 \%$ levcls significantly improved the BW. BWG and FCR recorded at $3^{\text {rd }}, 4^{\text {th }}, 5^{\text {th }}$ and $6^{\text {th }}$ weeks of the experiment (Table 2). Aletor et a. (2000) found that supplenienting the diet with amino aclds improved growth of brollers. Also, Sterling and Pestl (2003) demonstrated that different levels of supplemerital lysine in. creased BWG of broller chkcks from 0 to 21 days of age. The improvement in BW of broiler chicks fed LCP-diets supplementer with L lystre indicated that bysine gupplementation improved proteln utlizzation (EL-Sherbing et al., 1097 and Bhelien, 2001). With this concept. Abdnilah ot al. (2005) round that BWG and FCR of broiler chicks fed LCP-dlets (20 to $18 \% \mathrm{CP}$ from 0 to $3 \mathrm{wk}$ and 18 to $16 \% \mathrm{CP}$ from 4 to 7 wk of agel supplemented with methlomine and lysine was not significaritly dufferent from those fed the 23 to $20 \%$ CP-dlet. SImllarly, Khan et al. (2010) found that reduction of proteln level from 23\% to 19\% had no detrimental effects on BWG when supplemented with lysine. The improvement in WG with LCP-diet supplemented with EAA could be due to reduced heat increment. which was assoclated with the metabollsm of excess proteln. Reduced heat increment led to reduced heat stress and therefore. Improved WG.

The effect of decreasing the detary crude protedn level by $10 \%$ in the present study resulted in high feed Intake and FCR whatever the dlet supplernented with excess lysine or not (Table 9). The recorded FCR are 1.89 for the control diet compared to 2.54 , 2,42 and 2,28 for the LCP-dlet supplemented with $0,0.2 \%$ or $0.4 \%$ lysine diets. respectlvely. Nacdmento. (2009) found that increasing dletary lysine levels for brolkers and balancing the esential amino acids Improved FCR without modifying the feed intake because of the Inerease of muscular growth and body welght galn. Similarly. E-Huseoing 
et al. (2004) and Tmmazakl et al (2006) found that feed lalake of broller chicks was not slgniflcaritly affected by LCP amino acld supplemented diets. Also, Corzo et al. (2004. 2006) reported that Increasing ly. sine only improved FCR whthout affecting FI. In addition. Sterllng th al. (2008) found that Increasing dletary lyslne Improved both FI and FCR and increased BWG. On the other hand. Khan et al. (2010) Indlcated that there was an Increase in FI as CP levels were de creased from $29 \%$ to $19 \%$ but whthout affectIng FCR.

Data of the dressed carcass of broiler chicks fed LCP.dicts (1040) and supplemented with lystne $(0,0.2$ or 0.406$)$ revealcd that dccreasing dietary proteln signiflcantly decreased carcass welght and tricreased abdominal fat. Lysine supplementation by 0.456 over that of NRC (1204) significantly Improved dressed carcass and reduced abdominal fat (Table 3). Kerr and KJdd (1999) found that a reduetion in dietary CP de. creased rarcass ylelds. Increased abdoml. nal fat. and decreased breast meat yteld. Increasing fat accretson tri brollers fed the LCP-dlet may be attitbuted to increased focd intake as an attcmpt to mcet thels proteln and arnino acld requirement and the extra energy consurned will be depositcd as Iat. Simllarly. It was found that abdominal fat was signiflcantly Increased in assoctatlon with feeding low CP dlet 118 to 1606) in the finlsher pertod (Yonemochl et al. 2003; and Yamaxaly et al., 2006]. How. ever, it is clear from our results that the LCP. dlet supplcmented with $0.4 \%$ lystne dccreascd carcass fat deposition near to that of the control diet.

\section{Serum metabolites and Hil titer}

The study of the data related to serum metabolttes (Table 4) showed that decreasing DCP level by 1096 than that of NRC (1994) signlficantly ( $p<0.05$ ) decreased serum lotal proteins, albumin and globulln and increased total llplds, trlglycendes, cholesterol, HDL, and LDL. Iysine supplementation by 0.496 above that of NRC (1994) to the LCP diets increased serum total protelns. The increase in plasma protelns was concurrent wh an inerease (P<0.05) in plasma albumin (nom specific tamune factor) and an increase $\{P<0.05\}$ in glob ulin, the spectfle immune factor and a decreasc $(P<0.05)$ in $A / O$ ratlo. The decrease In total IIpIds, triglycerldes, cholesterol, HDL and LDL in brollers were not signifcantiy (p<0.05) different from that of the brollers fec the nor mal recommended detary protein and lysine levels. Thomas and Combs (1967) indicated that feeding a LCP-diet decreased total plasma protell and vice versa. This may be attrlbuted to the finding of Furper (1975) who found that dietary protein served as a precursor for plasma protelus. However, Coxzo t al. (2008) reported that total plasma protein was not affected by feeding LCP-diet supplemented with EAAs and NFAAs. On the other hand. Kammal and Awndalla (2007) fed the broller chicks 2\% LCP dlet with increasing uthlizable lysine and methiondne levels by 0.25 $-0.1 \%$ and $0.2-0.1 \%$ In starter and findsher dlcts respectively and found signiflcant úcreases in serum tolal proteln and albumin.

The effects of leeding the LCP-dlet with ly sine supplementation on haemagglutination Inhibition (HI) titer to NDV are presented in table 4. At 7 day post vacchation (14 days of apel. the Hl thter was low lor broller chick fed 
LCPdlet supplemented with 0 or $0.2 \% \mathrm{ly}$ sine. However, lysine supplementation by 0.490 of the diet increased HI Uter. By 21 day of age. the HI titer of all treatment stert to increase however the highest titer was for the control group followed by broller chicks group fed LCP-diet supplemented wh $0.4 \%$ lysine which were not signiflcantry different from the control group. At 28 day of age, the HI titer of different broller groups reach its highest value and the higher titer was for the broller chleks fed the recornmended $\mathrm{CP}$ and hysine levels lorlowed by the broller chicks fed the LCP-diet supplemented with $0.4 \%$ lysine and the lower Hl titer was recorded for broller chick fed the LCP dict supplemcnted with 0 , or $0.2 \%$ lysine. Carlomagno et al. (1980) found that protein deflclency inhlbited antibody production and the development of antiondy producing cells In response to $T$-dependent antigens. Aalbo and Kaham (1996) revealed that feeding broller chlcks vacclnated agalnst Newcastle disease dlets contalning high ME/CP ratios reduced IgM, IgG and HI titers. A deflelency of lysine may reduce immurse response of the chicken and resulted in a reduced effect of vaecination. Chen et al. (2003) showed that lysine had an influence on chicken immune function and humbral immunity assay and cell mediated immunity funetion and showed a reduction in antuboty response to NDV vaccination in broller chlckens fed a lysine- denclent diet. Also, moning et al. (2000) found that increasling the dietary concentration of lysine Improved the haemapglutination and agglutunin ttres. and IgG and lgM levels. Sim1larly, Manzoor et al. (2003) revealed that birds on high protein diets showed higher antbody and cell medlated responses than birds on low protein diets. From the present study It could be concluded that dietary protein level could be reduced by $10 \%$ of recommended level with supplementation of lystrie at a level of $0.4 \%$ above the recommended level with no adverse effect on growth performance, serum metabolites and immune response. 
Tible 1. Ingredient and chemical composition of the experinental diets provided with or without lysine for brolker ehicks

\begin{tabular}{|c|c|c|c|c|c|c|c|c|c|c|c|c|}
\hline & \multicolumn{12}{|c|}{ Experipatata dots } \\
\hline & \multicolumn{4}{|c|}{ Stakn } & \multicolumn{4}{|c|}{ Grower } & \multicolumn{4}{|c|}{ Finisiont } \\
\hline & Cosstre: & $\begin{array}{l}\mathrm{LP10 \%} \\
\mathrm{NL}_{\mathrm{L}}\end{array}$ & 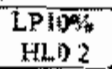 & $\begin{array}{l}\text { Plow/ } \\
\text { HiLO4 }\end{array}$ & catuluol & $\begin{array}{c}\mathrm{CP} \\
\mathrm{N}\end{array}$ & $\begin{array}{l}\text { LP10\% } \\
\text { H:LOL.2 }\end{array}$ & $\begin{array}{l}\angle P 10 \% \\
\text { III } 0.4\end{array}$ & Conuti & $\begin{array}{c}\mathrm{LPI} W^{* / / 3} \\
N L\end{array}$ & $\begin{array}{l}I P J 0^{3} \% \\
\text { HLOZ }\end{array}$ & $\begin{array}{l}\text { LP10\% } \\
\text { FELA A }\end{array}$ \\
\hline \multicolumn{13}{|l|}{ Ingredients } \\
\hline Corn, yefkow & 54,00 & 50.21 & 59.60 & 58.24 & 59.30 & 674 & 83.20 & 69.100 & $65 \times$ & $69.5 ?$ & $(9,9) 2$ & 69.60 \\
\hline Soyteany meal & 2998 & 24.58 & 24.58 & .24 .58 & 2765 & 34.70 & 24.70 & $24: 0$ & 250 & 22.20 & 22.45 & 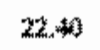 \\
\hline Fis thes & 7.000 & $7 . m$ & $7 x$ & $7 \infty$ & 3.50 & $2 x$ & 2.60 & 2.60 & 1.25 & $0 i 2$ & 0.75 & 0.75 \\
\hline Soytemal ail & E.:D & $\sin 3$ & 562 & S.Diz & $52 n$ & 3.55 & 553 & 5 & 4.75 & 4.50 & 4.50 & 4.5䊂 \\
\hline Likge sone & 187 & 2.50 & $\cdots i 1$ & $22 \mathrm{~s}$ & 8.90 & $21, n$ & 2.00 & 1.94 & 2.00 & 2.18 & 2.18 & 2.00 \\
\hline Drtat phasphate & 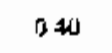 & 048 & i) 34 & $0+1$ & . & - & . & $*$ & - & " & $\cdot$ & - \\
\hline Comitran sales & 0.3 & f) 3 & 05 & 0.3 & 03 & 0.3 & 03 & 0.3 & 0.3 & 0.3 & 03 & 03 \\
\hline Mis s Sith prenix* & 225 & 025 & $12 x$ & 0.25 & 0.25 & 0.5 & 0.25 & 0.25 & 0.25 & 0.25 & 0.25 & 0.25 \\
\hline 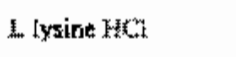 & - & ois & 0.45 & 075 & . & a) 1 & 0.35 & 0.60 & - & 0.15 & 0.45 & 0.70 \\
\hline DL intetionint & 4.10 & D. 10 & $n 1 n$ & io & 0.191 & 0.10 & 0.10 & 1) 10 & 0,10 & 0.10 & 0.10 & 010 \\
\hline \multicolumn{13}{|c|}{ Chemical tasulposition ( $(n / \%)$} \\
\hline$\%$ & 22.84 & 20.10 & 3086 & 20.80 & 19.89 & 18.20 & 1811 & 18.08 & 17.88 & $\div 20$ & 16.28 & 16.20 \\
\hline $\mathrm{ME}(\mathrm{K}$ kaing & 3196 & 3205 & $3 \mathbf{w 2}$ & 3203 & 3197.79 & $3201 . ?$ & $3(9)$ & 3196 & 3102 & 32005 & 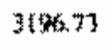 & 3124 \\
\hline C* & 1.07 & 119 & 117 & 1.17 & 0.82 & 0.86 & 0.86 & 0.84 & 0.83 & 0.88 & 0.879 & asis \\
\hline Arailabies & 0.54 & ij.s & DS: & 052 & 0.41 & 0.37 & 0.18 & 0.37 & 0.37 & vis & 0.35 & 0.3 .5 \\
\hline$L \sin x$ & 130 & 1.30 & 150 & 1.70 & 1.05 & 134 & 1.21 & 1.40 & 0.03 & 092 & 1.348 & 1328 \\
\hline Methiontae & 0.52 & 0.52 & 0.52 & $u ! 2$ & 0.40 & 0.41 & 0.42 & 0.42 & 0.36 & 0375 & 037 & 0.378 \\
\hline
\end{tabular}

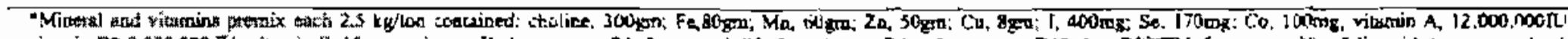

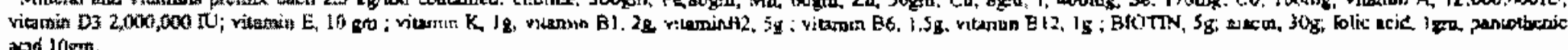
of and logra. 
A. H., Orma; et al..

Table 2. Effect of dielary protein level and iysine supplementation on the weekly body weight development, body weight gain (g) and feed conversion retio of brailer chickens

\begin{tabular}{|c|c|c|c|c|c|}
\hline & & \multicolumn{4}{|c|}{ Dieiory Froteln \& byalne levels (\%) } \\
\hline & & & \multicolumn{3}{|c|}{$10 \%$ lower than reconm naded } \\
\hline \multicolumn{2}{|c|}{$\begin{array}{l}\text { Lysine supplementation } \% \text { p } \\
\text { Lup perlot }\end{array}$} & Control & 0 & 0.1 & 0.4 \\
\hline & Inilial bocty weigha, $B$ & $4.6 \pm 0.42$ & $45.39 \pm 0.46$ & $44.35 \pm 0.54$ & $44.66 \pm 0.41$ \\
\hline \multirow[t]{4}{*}{0.1} & Body weight, & $134.9^{4} \pm 1.91$ & {$\left[33.9^{*} \pm 2.25\right.$} & $124.6^{\circ} \pm 1.97$ & $125.3= \pm 1.99$ \\
\hline & gody gatn, 8 & $50.31^{2} \pm 1,81$ & $88.58 * \pm 1.91$ & $80.23^{d} \pm 1.63$ & $03.95^{104} \pm 1.624$ \\
\hline & Feed consumplion, 8 & 123.00 & 160.44 & 138.42 & 142.7 \\
\hline & Feed conversion ratio & $1.38^{6} \pm 0.03$ & $1.59^{x} \pm 0.039$ & $1.74^{4} \pm 0.032$ & $1.71^{8} \pm 0.029$ \\
\hline \multirow[t]{4}{*}{$i-2$} & Body weight 8 & $327.697 \pm \$ 02$ & $281.7 \pm 6.03$ & $285.18^{-1} \pm 7.14$ & $299.17^{\star} \pm 7.86$ \\
\hline & Body gain. i & $102.73^{\circ} \pm 3.6 \mathrm{I}$ & $147.7+3.67$ & $162.06^{\text {tat }} \pm 3.66$ & $17.55^{m+m} \pm 6.23$ \\
\hline & Feod corrsumption, & 290.45 & 322.33 & $327.7 \gamma$ & 314.4 \\
\hline & Feed convergion ratio & $1.52 \pm 0.03$ & $2.22+ \pm 0.06$ & $2.00 \% \pm 0.07$ & $1.087 \pm 0.07$ \\
\hline \multirow[t]{4}{*}{$2-3$} & Bady weight, 8 & $615.3^{n} \pm 1252$ & $547,5^{k} \pm 14.08$ & $559.83^{4} \pm 16.05$ & $592.00^{\infty} \pm 15.73$ \\
\hline & Ecody gain. $\mathrm{B}$ & $287.3 \pm 9.23$ & $265.8 \pm 10.78$ & $273.18 \pm 11.71$ & $200.75 \div 9.26$ \\
\hline & Foed consumplion, s & 473.23 & 613.46 & 576.66 & 589.32 \\
\hline & Peed conversion ratio & $1.68+0.058$ & $2.40^{\circ} \pm 0.095$ & $2.21 * \pm 0.09$ & $2.00^{6} \pm 0.067$ \\
\hline \multirow[t]{4}{*}{$3-4$} & Body weight $B$ & $1012.5^{2} \pm 258$ & $275.9 \pm 22.06$ & $548.87^{h} \pm 21,22$ & $964.69^{+}+24.79$ \\
\hline & Body goin, s & $397.33 \pm 16.17$ & $378.4 \pm 12.36$ & $389.03 \times 14.48$ & $392.66 \pm 17.07$ \\
\hline & Feed consumpcign, 8 & 690.66 & 96035 & 918.61 & 873.73 \\
\hline & Feed conversion ratio & $1.84 \pm 0.1$ & $2.53^{\circ} \pm 0.1$ & $2.36^{6} \pm 0.08$ & $2.35^{b}=0.10$ \\
\hline \multirow[t]{4}{*}{$4-5$} & Body weight, g & {$[447.7 \pm 26.6]$} & $1285.3^{4} \pm 77.75$ & $1360,95^{69} \pm 29,30$ & $1990.35^{\star} \pm 11.77$ \\
\hline & Body gain 8 & $415,2 \pm 2139$ & $360.44^{\circ}=12.80$ & $412.06^{*}+19.30$ & $409.63^{* t}=15.64$ \\
\hline & Ered unsumplion, s & 520.33 & 982.08 & 1074.85 & 990.36 \\
\hline & Feed conversion ratio & $2.26^{6} \pm 0.11$ & $2.72^{*} \pm 0.10$ & $2.000 \pm 0.13$ & $2.54 * 0.094$ \\
\hline \multirow[t]{4}{*}{$3-6$} & Buojy weighte, & $1941.8 \pm 37.36$ & $1710.33^{\circ} \pm 35.35$ & $1816.66^{\circ} \pm 32.77$ & $1874 . \pm 4 i .20$ \\
\hline & Bady win : & $494.14^{\circ} \pm 16.50$ & $423.66^{\circ} \pm 19.54$ & $475.73^{\circ} \pm 20.99$ & $484.1+16.38$ \\
\hline & Feed annempticn, $g$ & 1090.05 & 1199.43 & 1287.14 & 1217.9 \\
\hline & Feed conversion ralis & $2.29^{b} \pm 0.09$ & 2.8240 .09 & $2.70^{2}+0.17$ & $2.60^{\circ} \pm 0.10$ \\
\hline
\end{tabular}

Mansoura, Vet. Hed. J.

Vol. XII, No. 1, 2010 
Table 3. Erreei of dietary protein level and lysine supplementation ou growth performance and carcass qualify (mesn $\pm S E$ ) of broitus chickens

\begin{tabular}{|c|c|c|c|c|}
\hline \multirow[b]{3}{*}{$\begin{array}{l}\text { Lyalae } \\
\text { supplementadian \% }\end{array}$} & \multicolumn{4}{|c|}{ 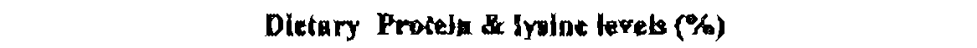 } \\
\hline & \multirow{2}{*}{ Cantral } & \multicolumn{3}{|c|}{$10 \%$ lower than recommended } \\
\hline & & $\boldsymbol{0}$ & 1. 2 & 0.4 \\
\hline \multicolumn{5}{|l|}{ Items } \\
\hline Live boudy weight $(g)$ & $1941.84^{\mathrm{I}} \pm 37.36$ & $1710.22^{4}+3535$ & $1916.56+32.27$ & $1874,36+41.20$ \\
\hline Bad weight gain (g) & $1897.19^{2} \pm 37.26$ & $1664.60^{5} \pm 35.05$ & $1792.31^{b} \pm 32.102$ & $1829.93^{-1} \pm 40.97$ \\
\hline Feod intake 48 ) & 3590.54 & 4234.18 & 4323.45 & 128.49 \\
\hline Feed converaion ratia & $1,89^{10} \pm 0,03$ & $2.14^{\prime \prime}+0.03$ & $2 . \$ 2^{6} \pm 0.04$ & $2.2 x^{6} \pm 0.05$ \\
\hline Proleitr ell cixney recio & 2,87 & 2.32 & 2,49 & 2.62 \\
\hline Cost ôे $K_{8} \mathcal{B W}$ & 3.81 & 3.12 & 4.94 & 4.71 \\
\hline Dressod carcess $\%$ & $73.40^{4} \pm 2.75$ & $63.91^{b}+445$ & $67.54^{\mathrm{t}}+2.44$ & $69.58^{\star} \pm 1.65$ \\
\hline Abutominal fat & $1.10^{\circ} \pm 0.11$ & $1.88^{2} \pm 0.14$ & $1.50^{\mathrm{b}} \pm 0.0 \mathrm{~B}$ & $133^{60} \pm 0,06$ \\
\hline
\end{tabular}

Table 4. Effect of dielary protein levels and Jysine supplenentation on serum metabolites and HIT of broilla chickens.

\begin{tabular}{|c|c|c|c|c|}
\hline \multirow[b]{3}{*}{$\begin{array}{l}\text { Lyoline auplen. } / 6 \\
\text { lems }\end{array}$} & \multicolumn{4}{|c|}{ Dlet. Protein $\alpha$ lyulate levels $(\%)$} \\
\hline & \multirow{2}{*}{ Conatrol } & \multicolumn{3}{|c|}{$10 \%$ bower than recalnumended } \\
\hline & & $\mathbf{0}$ & a.2 & 0.4 \\
\hline Totel prolsin (mg'dn) & $4.04^{1} \pm 0.14$ & $2.49^{6} \pm 10$ & $2.64^{c} \pm 0.18$ & $2.88^{h} \pm 0.11$ \\
\hline Albuain $(g / d)$ & $1.75: 0.05$ & $1.45^{\circ}+0.07$ & $1.48^{b} \pm 0.02$ & $1,62 b^{b}=0,06$ \\
\hline Globulin ( $g / d$ d) & $2.28^{*} \pm 0.199$ & $1.04 \pm 0.07$ & $1.17 \pm 0.14$ & $1.26^{k=0.08}$ \\
\hline NG revio & $0.76^{\circ} \div 0.11$ & $1 \times 30 \times 11$ & $1,28^{\star}{ }_{* 0,13}$ & $1.20^{*}+0.07$ \\
\hline Gilucote $(\mathrm{mo} / \mathrm{dl})$ & $10,2 x+2.66$ & $111.00 \pm 4.23$ & $109.41,98$ & $10.66 \pm 3.32$ \\
\hline Tolal lipid (jold) & $398.59^{\circ} \pm 1.05$ & $529.34 \pm 3.96$ & $503.24^{6} \pm 7.26$ & $448.82 \pm \pm 8.95$ \\
\hline Toual chotesserol (iofutdy & $140.05^{4}+6.25$ & $197.59 \pm 3.69$ & 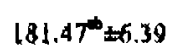 & $172.23^{\mathrm{k0}} \pm 6.54$ \\
\hline Triglyeerides (ndg/d) & $53.23^{\circ} \pm 1.32$ & $90.8 L^{4} \pm 3.95$ & $84.08^{\omega}+2.57$ & $77.37^{\mathrm{l}} \pm 1.92$ \\
\hline HDCP $(\boldsymbol{m} q \mathrm{~d} d)$ & $\alpha .0 s^{x} \pm 3.21$ & $120.65^{\circ} \times 4.40$ & $100.65^{\infty} \pm 5.60$ & $98.37^{* 0} * 1.75$ \\
\hline LDL (m/di) & $41.54^{6} \pm 2.88$ & $67,16^{2} \pm 4.80$ & $62.25+2.23$ & $18.3^{*}+3.10$ \\
\hline HI titer $(\log 2)$ at 14 days & $6,24^{x} \pm 0,22$ & $4.03^{6} \pm 0.20$ & $4,28^{\phi} \pm 0,31$ & $5.53+0.34$ \\
\hline Hil hiter (log'2) a 21 days & $6.62 * 0.25$ & $5.05^{4}=0.22$ & $5.26^{\circ} \pm 0.38$ & $6.20^{\mathrm{m}} \pm 0.50$ \\
\hline HI citer $(10-2)$ ax 28 day & $9.92 \pm 0.30$ & $7.01^{5} \div 0.2 .8$ & $7.69^{b x}=0.40$ & $8.94^{+t}+0.47$ \\
\hline
\end{tabular}




\section{RHAFRANCES}

Aldallah, A G.; Bollmwi, A Z. and Saud. M. (200s) : Response of brollcr chicks to lowproteln diets supplemented with amino ac ids administered through feed or drinking wa. ter under heat stress eonditions. Anlmal Production Research Institute, Second Conierence and the Reglonal Sympostum on Buffalo Production and Future prospects, Sakha. Kafr El Shclkh. Egypt.

Aletor, V. A.; Humid, I. 1.; Micp, E. and Pfoffer, E. (2000) : Low-proteln amIno actdsupplemcnted diets in broller chickens: $E$ rects on performance, carcass charactertstics. whole-body composition and efficlencies of nutrient utlization. J. Sct. Food Agrite. 80: 547-554.

Allatn, C.; Poon, L. and Chan, C. (1974): Enzymatic detcrmination of total serum cholesterol. Clin. Chem 20, 470.

Alloman, F. and Leclereq, B. (1897) : Effect of dletary protein and environmental temperature on growth performance and water consumptlon of male broller chickens. Br. Poult.Scl.38: 607-610.

Ambo, J. O. nnd Kabasa, J, D, (1896) : Serum Immungglobulln responses among brotler chickens fed ugandlan commerclal poultry feed and vaccinated againel Newcastle dlsease. Trop - Antma. Smence Prod. 28: 163173.

AOAC (1000): Assoctation of ofticial analytical chemist. Offlctal unethods of Analysts. $13^{\text {th }}$ Ed. Washington DC.USA.

Artla, Y. A: Naqax, M. E.; Oaman, M. and Abd-Elhady, 8. B. (1998): optimum levels of metaboltzable cncrgy and crude proteln In the raluons for Avlan 34 broller chlcks. Fro ceeding. $10^{\text {th }}$ Confercice of Esyptlan Soclety of Animal Production. Asslut Univ-ersity.
Egypt pp, 223-241.

Bursteln, Mi; Bcholnick, H. and Morfin, R. (1970) : Rapld method for leolation of 11popro- telna from human serum by predpitation with polyanions. Joumal of lipid research 11 .. 583-595.

Cariomagoo, H. A; Allto, A E.; Rlfe, $s$. U. and Gmeno, A L. (1900) : B cell Immune respanse during totalproteln deprivation. Acta Physiol. Lat. Am.. 30:187-192.

Chen, C.; Bander, J. E. and Dale, N, M. (2003): The effect of dtetary lysine deficlency on the tmmune response to Newcastle dtsease vaccination In chickens. Avtan. Dis. 47: 1346135!.

Carzo, A; Dolzer, W. A and Bldd, M. T. (2006) : Dietary lysine needs of late-developIng heavy brollers. Poult. Scl., 85: 457-461.

Corzo, A: Frtetw, C. A; Fidd, M. T. and Kerr, B. J. (2006) : Response of broller chicks to essential and non-essential amino acld supplementation of low crude proteln diets. AnIm. Freed Scl. Technol. 118:319-327.

Corzo, A.; Bidd, M, T.; Bumham, D. J. and Eerr, B. J. (2004) : Dietary glycine needs of brofler chicks. Pault. Sc1. 83; 13 82-13 84.

Doumas, B.; Waston, W. and Blegr. $\mathrm{K}$. (1971) : Alburnin Standards and the measurement of serum albumlnwith brancresol green. Clin. Chim. Acta.31. 87-96.

Elto, R. M.; Kwolkel, R. P.; Verategen. H. W. A and Denkartog. $L, A(2008)$ : Dietary balanced proteln in broller chickens. 1 . A flexdble and practical tool to prediet doseresponse curves. Br. Foultry Sci. 46(3); 300. 309.

El-Huasolny, O. M.; Abou ElWafa, 8. and EIkomy H. A. A (2004) : Nutrients allowance for broller performance. Egypt. Poult. Sct. 24: 575-595. 
El-Sherblay, A E.; Mathmed. M. A. Hamza, A B. and EAarr. T. M. (1987) : Resp-onse of broller chtcks to low proteln dies supplemented with lysine and methionine. Egypt Poult. Sct. 17: 2328-5595.

Fanoatl, P, and Precipe, I. (1962) : Serum triglyccrides determined calorime rically with an enzyme that produce hydrogen peroxıde. Princlple. J Clink. Chemistry 28, 20-77.

F1rman, J, D. and 8. D. Bollng (1008) : Idcal protein in turkeys. Poult. Sc1., 77: 105. 110 .

Friede Wald, W.; Levy, $R$. and Fredertokcon, D. (1872) : Estimation of the concentrauon of low Jcnsity llpoproteln cholesterol in plasina with out use of ultra centrifuge. Clin. Chem. $18,499-502$.

Goarnal, A; Bardawlil, C. and Davld, $M$. (1949) : Determination of serum proteln by means ofbiuret reaction .J. Blol chem. 177TS1.

Harper, H. A (197b) : The blood, lympl and ccrebrogpinal fluld. Chapter 10 in Revlew of Physiologlcal Cheristry $15^{\text {th }}$ ED. By Harper, H.H. LANG Medical Publications.

Iohbponanl, N. S.; Lodhl, G. N. and Ichhponanl, J. 8. (1981) : Effect of supplementIng lysine and methionine in the vegetable proteln diets on the performance of trollers. Indlan lournal of Poultry Science. 16: 28-43.

Iwe, M. $O$. and Oradipe, O. O. [2001] : Effect aI addition of extruded full-fat soy nour into sweet potato llour on furctional propertles of the mixture, J. Sustaln. Agri. Envtron. 3: $109 \times 117$.

Kanmal, A and Apadalla, S. A (2007) : Effect of levels of proteln and amino acids (methlonine and ysine on some blochemical parameter and performance of brollers. $J$. Egypt. Vet. med. Aase. 67, no 2: 123-134.
Kerr, B. J, and rald, M. T. (1999) : Am no acid supplcinentation of low-pioteln broller diets : 1. Glutamic acld and indispensable amlno acld supplemencation. J. Appl. Poultry Res. 8:299-309.

Khallta. M. M. (2001) : Effecc of proteln/ energy leeding systems on the perlomance of two local chicken strains. Ph. D. Thesls, Faculty of Agrieulture- Kr- El-Shelkh. Tanta Unlversity.

Khan, S.; Jabbar, M. A; Metnuud, A. Abba5, M. M, and Mahmood, A (2010) : Eflect of lysine supplementauon in low protein diets on the performance of growting brollers. Pakd stan Vet J, 30 (1): 17-20.

Rldd, M. T.; Kerm, B. J.: Firman, J. D. and Dollng. S. D. [1896) : Grouth and carcass characteristics of brollers fed low proteln-threonlne supplemented diets. I. Appl. Poult. Res. 5: $180 \cdot 190$.

Klaslag, K. C. and Calvert, C. C. (2000) : The care and reeding of an Immune system: an analysls of lysine needs. Proceedings of the VIIth International Sympostum on Protein Metabolisr: and Nutrition. G. E. Lobley, A. White and J. C. MacRae. Wageningen, WagenIngen Press: 253-264.

Mansoor, A; Cheema, M.; Gureahl. A and Haventeln, G. B. [2003] : A contparson of the Immnne protile of commercial broller stralns when raused on marglnal and high proteln diets. [nt. J. Poult. Scl. 2 (5): 300.

May. J, D.; Lott, B. D. and Simmons, J. D. (1998) : The eftect of environmental teunperature and body weight on yrowth rate and feed galn of male brollers. Poult. Sci. 77 : 499 501 .

Natum, K. H. (2002) : Efflclent feed nutuent utrlization to reduce pollutants in poully 
and swine manure, Crit. Rev. Envtron, Scl. Technol. 32 (I): 1-16.

Namrond, K. F.; Shivaznd, M. and ZaghaI, M. (2008) : Effects of fortfying low crude protein dict with crystaline amino aclds on performance, blood ammonla level, and excreta characteristics of broller chicks. Poultry Scl. 87:2250-2258.

Nagcimento, A A (2009) : Lisina otimlza a converse allmentar. Revista Ave World. Anol, n.5. outubro/novembro. p. 4850.

NRC (1904): Natjonal Rescarch Council. Nutrient Requirement of Poultry. 9th Rev, ed. National Acaderny Press, Washington, DC. Nworgu, F. C., Egountke, G. N. Faphohunda, J. B. Ogundola, F. O. Omela, A. G..

Ogbonuka, G. E. and Okpere, C. N. (2000) : Performance of broller chtcks fed fullfat extrudcd soybear meal and full-fat soybean meal Trop. AnIm. Prod. Invest.. 3: 4754.

Payme, C. J.; Scott, T. R.: Dick, J. W. and Glick, B. (1900): lmmunity to Pasteurella multoclda in proteindefictent chickens. Poult. 5c1., 69: 2134-2142.

Saedecor, Q. W, and Cochran, W. G. (1967) : Staustical Methode. 6th ed., Oxford and $18 \mathrm{~N}$ Publlshing CO. Calcutta, PR. 344346 .

Sterling, K. G. and pesti, G. M. (2003) : Pcrformance of brotler chicks fed various levels of dietary lysine and crude protein. Poult. Sci. 82: 1939-1947.

Storling, E, Gri Peath, G, M. and Bakall. R. I. (2006) : Performance of different broller genotypes fed diets with varying leveis of die- tary crude proteln and lysine. Poult. Scl. 85: 1045- 1054.

Thomas, O. P. and comba. G. F. (1003): Relationshlp between sermm protein level and body composition in the chlck. J. Nutr., 91 : 468*478.

Trindor, P. and Ann, D. (1069); Glucose; Enzymatlc Colormetric Test (COD-PAP). Clln. Biochem.6:24.

Talagbe, V. K.; Cook, M. E.; Harper, A. E. and 8ande. M. L. (1987): Enhanced immune responses in broller chickens fed methioninesupplemented dfets. Poultry Sclence 66 . 1147-1154.

Wobel, D. M.; Johneon, R. W. and Baker, D. A. (1898) : Lupopolysacchartde-Indueed reductions in food intake do not decrease the efBciency of lysine and threonlne utlitzation for protein accretton in chickens. Journal of Nutrition 128, 1760-1766. Poult. Scl., 55: 243" 253.

Yamazald, M.; Muratemil, H.; Natreahlma, K.; Abe, H. and Thkomasa, M. [2000] : Efrects ofexeess andno aelds in low proteln diet on abdominal fat deposition and nitrogenexcretionofthe broller chicks. J. of Poult. ScI. 43: $150-155$.

Yonemoch, C.: Fuflaral, th and Takagl, H. (2003) : Effects of amino acld, enzyme mixture and phytase added to low proteln and low phosphons dlet on performance and excretion of nitrogen and phosphorus in brotlers. J. Poult. Set. 40: $114-120$.

zollner, N. and Elmeh, R (1062) : Determination of the total lipid concentration in serum, Zentralbatt Fur Cesamate Experimental Mediztn 135.545-549. 
A. M., Orma; et al...

الملنص العربى

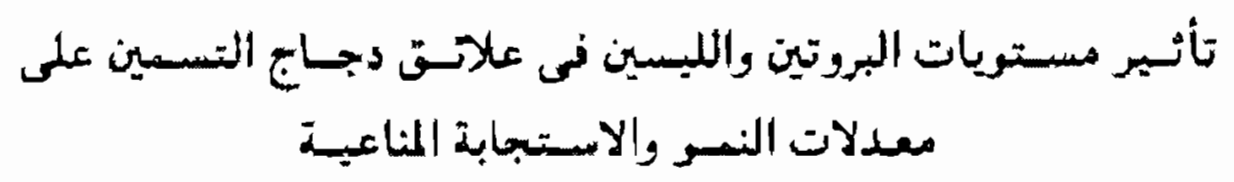

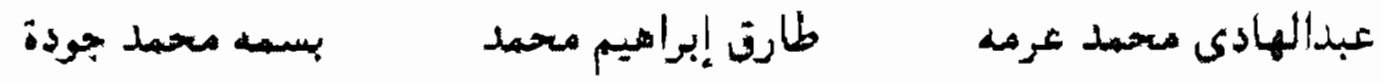

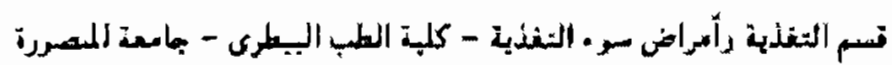

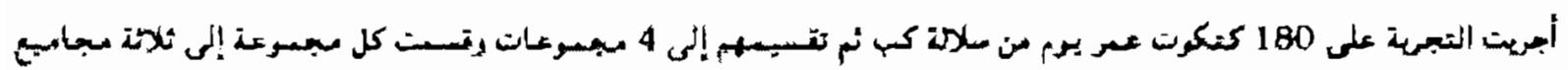

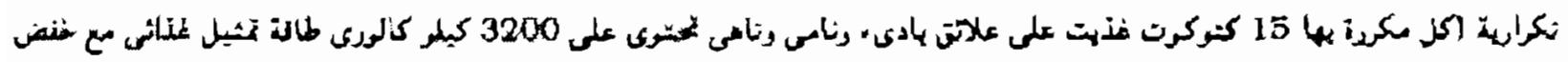

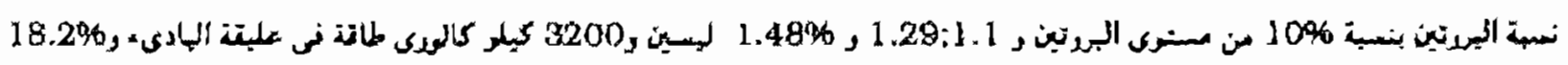

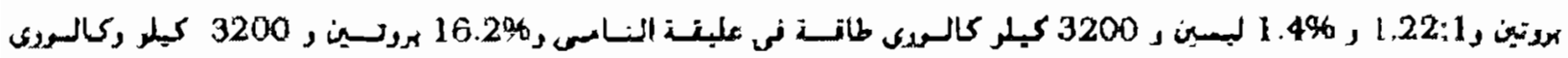

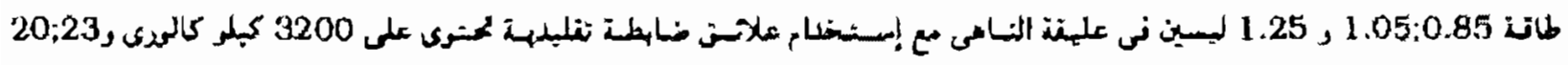

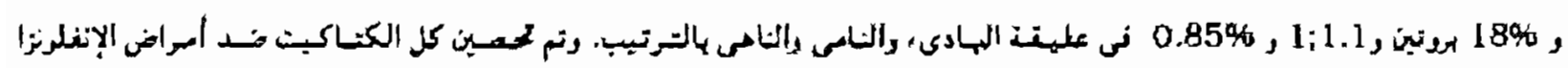

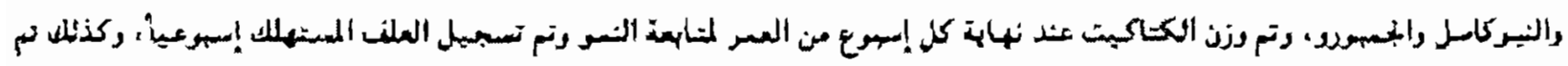

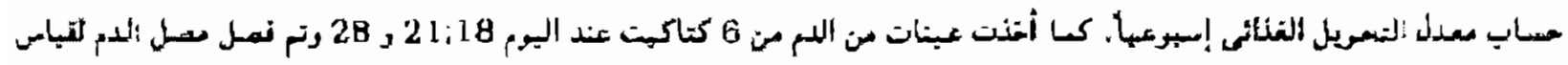

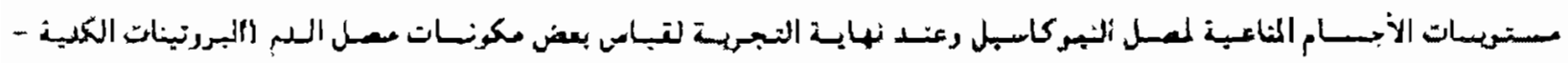

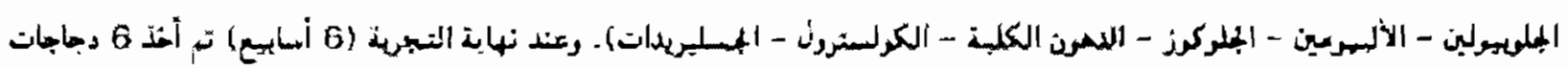

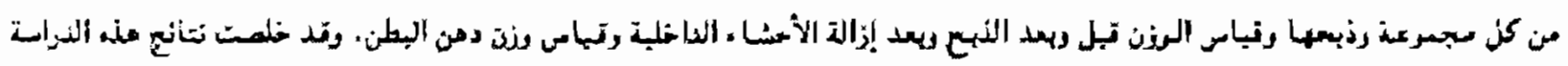
!

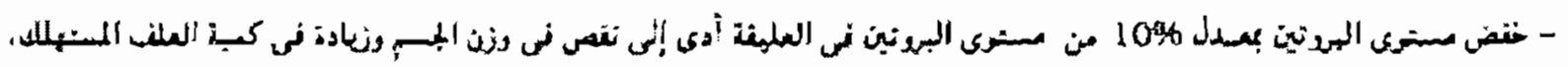

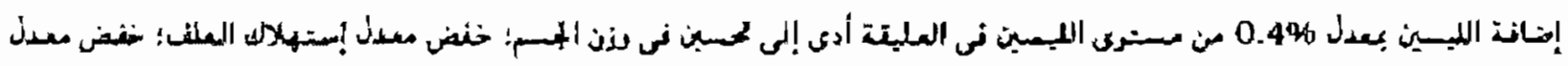

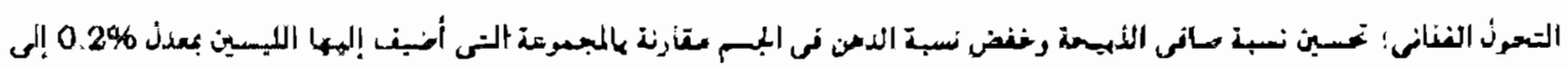

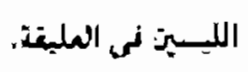

Marsoura, Vet. Med. J.

VoL. XW, No. 1, 2010 